\title{
Synthesis, Characterization and Antibacterial Studies of the Mixed Ligand Complexes of Pd(II) and Pt(II) Ions with Phthalic Acid and Heterocyclic Amines
}

\author{
Md. Belayet Hossain ${ }^{1}$, Md. Abdus Salam², Abdur Rashed ${ }^{3}$ and M.A.Yousuf ${ }^{1}$ \\ ${ }^{1}$ Department of Chemistry, Khulna University of Engineering \& Technology, Khulna-9203, Bangladesh \\ ${ }^{2}$ Department of Chemistry, University of Dhaka, Dhaka-1000, Bangladesh \\ ${ }^{3}$ Fish Inspection \& Quality Control, DoF, Khulna-9000, Bangladesh
}

Received: May 01, 2014; $\quad$ Accepted: May 26, 2014; $\quad$ Published (Web): July 23, 2014

\begin{abstract}
Mixed ligand complexes of $\mathrm{Pd}(\mathrm{II})$ and $\mathrm{Pt}(\mathrm{II})$ ions with phthalic acid and heterocyclic amines were synthesized and characterized. The general formula of the complexes is [MLL']; where, $\mathrm{M}=\mathrm{Pd}(\mathrm{II})(1-2), \mathrm{Pt}(\mathrm{II})(3) ; \mathrm{L}=$ phthalate, $\mathrm{C}_{8} \mathrm{H}_{4} \mathrm{O}_{4}, \mathrm{~L}^{\prime}=$ pyridine, $\mathrm{C}_{5} \mathrm{H}_{5} \mathrm{~N}(1)$; 2-aminopyridine, $\mathrm{C}_{5} \mathrm{H}_{6} \mathrm{~N}_{2}(2)$ and 4-picoline, $\mathrm{C}_{6} \mathrm{H}_{7} \mathrm{~N}(3)$. The complexes were synthesized in the solid form and characterized by elemental analysis, electrical conductivity, magnetic measurements, and spectroscopic studies. Spectral analyses and magnetic measurements revealed the coordination of metal ion with ligands and geometry of the complexes. Anti-bacterial activity of the complexes against seven pathogenic bacteria (three gram positive and four gram negative) was assessed by the disc diffusion method. Complexes $\left[\mathrm{Pd}(\mathrm{Ph})(2\right.$-apy) $]$ and $\left[\mathrm{Pt}(\mathrm{Ph})(4-\text { pico })_{2}\right]$ showed the highest anti-bacterial activity $($ when, $\mathrm{Ph}=$ bidentate phthalate, 2-apy $=2$-aminopyridine and 4-pico $=4$-picoline) .
\end{abstract}

Key words: Mixed ligand complex, phthalate, 2-aminopyridine, 4-picoline, anti-bacterial.

\section{Introduction}

Extensive antibacterial screenings of mixed ligand complexes revealed their importance in the biological processes. Several mixed-ligand complexes of $\mathrm{Pd}(\mathrm{II})$ and $\mathrm{Pt}$ (II) have been prepared and characterized by elemental analysis, conductivity measurements, I.R., electronic absorption and ${ }^{1} \mathrm{H}-\mathrm{NMR}$ spectroscopic techniques (Biyala et al., 2008; Sarmistha et al.,2008; Pandey et al.,2010). A very few survey has been done on the $\operatorname{Pd}(\mathrm{II})$ complexes with tridentate dianionic ligand pyridine-2,6dicarboxylate (Pablo at al., 1996). Some workers synthesized square planar $\mathrm{Pd}(\mathrm{II}), \mathrm{Pt}(\mathrm{II})$, and $\mathrm{Au}(\mathrm{III})$ terpyridine complexes and determined their physical properties, supramolecular constructions and biomedical applications (Eryazici et al., 2008).

There are many reports on $\mathrm{Pd}(\mathrm{II})$ complexes of heterocyclic amine with structural and magneto structural characterization (Shayma et al.,2010; Anshu et al.,2011; Edit et al. 2010; Kuduk-Jaworska et al. 2004). The metal complexes of phthalic acid have been studied both from pharmacological and industrial points of view as indicated by available literature (Reza et al., 2003). Some complexes of transition metal ion with malonic, phthalic and maleic acid are very important from antimicrobial and medicinal point of view (Reza et al., 2003; Islam et al., 2003). Considering these facts, the present paper describes the preparation of some mixed ligand complexes of palladium(II) and platinum(II) with phthalic acid $\left(\mathrm{PhH}_{2}\right)$ as primary and heterocyclic bases, viz., pyridine (Py), 2aminopyridine(2-apy), 4-picoline (4-pico) as secondary ligands and their antibacterial activity has been evaluated to perform primary selection of these complexes as therapeutic agents.

\section{Materials and Methods}

Chemicals and reagent: All the chemicals were analytical grade and were used as received. The solvents were purified using conventional methods.

Physical Measurement: Infrared spectra were recorded on FTIR spectrophotometer (IR-Prestrige-21) in the region $4500-400 \mathrm{~cm}^{-1}$ at the Department of Chemistry, University of Dhaka, Bangladesh. Carbon, hydrogen and nitrogen 
analyses were carried out by LECO CHEN-932, organic elemental analyzer, University Kebangsaan, Malaysia. Metal was determined by direct ignition method as oxide. The molar conductance of $10^{-3} \mathrm{M}$ solutions of the metal complexes in DMF was measured at $30^{\circ} \mathrm{C}$ using a Jenway 4310 conductivity meter and a dip-cell with platinized electrode. Melting points were determined using an electrothermal digital melting point apparatus. Magnetic susceptibility was measured by Magnetic Susceptibility Balance at $298^{\circ} \mathrm{K}$ (Model: Mk1, Sherwood Scientific, Cambridge, England) at the Department of Chemistry, University of Dhaka, Bangladesh. All susceptibilities were corrected for diamagnetic contribution using Pascal's constant (Vogel, 1961).

General method of complex preparation: An appropriate solution of $1 \mathrm{mmol}$ of metal(II) salts $\{\mathrm{Pd}(\mathrm{II})$ and $\mathrm{Pt}(\mathrm{II})\}$ in absolute ethanol $(25 \mathrm{~mL})$ was added to an ethanolic solution $(30 \mathrm{~mL})$ of phthalic acid $(1 \mathrm{mmol})$ with constant stirring at $70^{\circ} \mathrm{C}$. No precipitate was observed. Then $25 \mathrm{ml}$ of an ethanolic solution of heterocyclic amine bases e.g. $1 \mathrm{mmol}$ of Py (for complex 1), $1 \mathrm{mmol}$ of 4-pico (for complex 3) and $1 \mathrm{mmol}$ of 2-apy (for complex 2) was added to the resulting hot plate with constant stirring. The volume of the solution was reduced to $50 \%$ and allowed to cool at room temperature. The precipitate formed and was filtered, washed several time with ethanol and then dried in a desiccator over anhydrous $\mathrm{CaCl}_{2}$.

Antimicrobial screening: Seven pathogenic bacteria viz., Pseudomonas aeruginosa (Gram negative), Salmonella bovis morbificans (Gram negative), Salmonella typhi (Gram negative), Escherichia coli (Gram negative), Listeria monocytogenes (Gram positive), Staphylococcus aureus (Gram positive), Enterococcus faecalis (Gram positive) were collected from the Fish Inspection \& Quality Control Division, Department of Fishery, Boyra, Khulna, Bangladesh. Nutrient agar was used as bacteriological media. The complexes were dissolved separately in acetonitrile to get a concentration of $50-\mu \mathrm{g}$ disc $^{-1}$. Then in vitro anti-bacterial activity of these complexes was carried out by disc diffusion method (Rios et al., 1988; Bauer et al., 1966). The diameter of the zone of inhibition produced by the complexes was compared with Kanamycin $\left(30-\mu g \operatorname{disc}^{-1}\right)$.

\section{Results and Discussion}

Elemental analysis and conductivity measurement: The analytical data and their physical properties of the complexes are given in Table 1. The analytical data are in good agreement with the proposed empirical formula of the present complexes.

The molar conductance was measured in $N, N^{\prime}$ dimethyl formamide. The conductance values of the $\mathrm{Pt}(\mathrm{IV})$ complexes were in the range $(10.65-11.65) \Omega^{-1}$ $\mathrm{cm}^{2} \mathrm{~mol}^{-1}$ indicated that these complexes were nonelectrolyte in nature (Islam et al., 1991, 2002).

Magnetic moment: The observed magnetic moment of the complexes at room temperature is given in Table 1 . The magnetic moment values of the complexes indicated that these complexes are diamagnetic. This diamagnetism is supported by the small negative values obtained for their magnetic susceptibility. It appears from the magnetic moment data that the complexes of Pt(IV) ion display diamagnetic property and an octahedral geometry with $\mathrm{d}^{2} \mathrm{sp}^{3}$ hybridization which are consistent with the published structure (Islam et al., 1991, 2002).
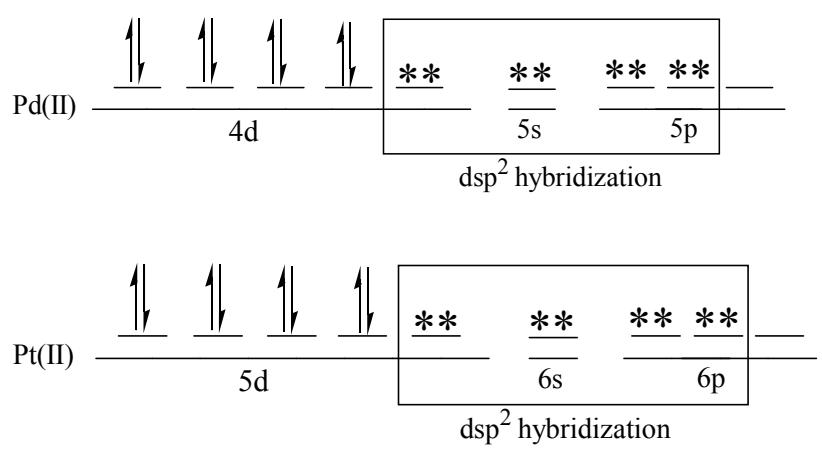

Infrared spectra studies: In the Infrared spectra strong band at $\sim 1686.78$ and $\sim 1404.20 \mathrm{~cm}^{-1}$ revealed the presence of carboxylic group of malonic acid due to $v_{\mathrm{C}=0}$ and $v_{\mathrm{C}-\mathrm{O}}$ which were shifted to $1610.0-1659.6 \mathrm{~cm}^{-1}$ and $1385.8-1399.3 \mathrm{~cm}^{-1}$ in the spectra of all the complexes. This indicates the coordination of malonic acid through the carboxylic group. The characteristic ring vibration of the heterocyclic amines in the range 1400-1600 $\mathrm{cm}^{-1}$ generally show significant changes on complexation but in our present complexes these bands could not be distinguished because of overlapping with $v_{\mathrm{C}=\mathrm{O}}$ and $v_{\mathrm{C}-\mathrm{O}}$ stretching bands. The in-plane and out-plane ring deformation modes of the heterocyclic amines observed at $\sim 520$ and $\sim 720 \mathrm{~cm}^{-1}$, respectively undergo a positive shift 
in mixed ligand complexes conforming a co-ordination through nitrogen. Presence of $\mathrm{M}-\mathrm{O}$ bonding is evident from the appearance of $v_{\mathrm{M}-\mathrm{O}}$ modes at $510.0-537.1 \mathrm{~cm}^{-1}$ in the spectra of the complexes. The presence of $\mathrm{M}-\mathrm{N}$ bonding in the complexes is evident form the appearance of $v_{\mathrm{M}-\mathrm{N}}$ modes at $421.4-470.0 \mathrm{~cm}^{-1}$. The infrared spectrum of amino pyridine shows $\mathrm{V}_{\mathrm{NH}_{2}}$ modes at $\sim 3443.96$ and $\sim 3193.21 \mathrm{~cm}^{-1}$. Both of thesebands are shifted to lower frequencies in the complexes (3) at $\sim 3320.2 \mathrm{~cm}^{-1}$ and $\sim 3056.0 \mathrm{~cm}^{-1}$, respectively which indicate the coordination with amino nitrogen (Hossain et al., 2004, 2012, 2012; Islam et al., 2004). Major I.R. spectral data for the complexes are given in Table 2.

Electronic spectra: The Electronic spectra of the $\mathrm{Pd}(\mathrm{II})$ complex in DMSO showed three spin allowed d-d transitions and two charge transfer bands. The bands were obtained at 22,800-23050, 28,300-28300, 31000-31300, 34800-35000 and $40000-40200 \mathrm{~cm}^{-1}$ corresponding to the transitions ${ }^{1} \mathrm{~A}_{1 \mathrm{~g}} \rightarrow{ }^{1} \mathrm{~A}_{2 \mathrm{~g}},{ }^{1} \mathrm{~A}_{1 \mathrm{~g}} \rightarrow{ }^{1} \mathrm{~B}_{1 \mathrm{~g}},{ }^{1} \mathrm{~A}_{1 \mathrm{~g}} \rightarrow{ }^{1} \mathrm{E}_{\mathrm{g}},{ }^{1} \mathrm{~A}_{1 \mathrm{~g}} \rightarrow$ ${ }^{1} \mathrm{~A}_{2 \mathrm{u}} \&{ }^{1} \mathrm{~A}_{1 \mathrm{~g}} \rightarrow{ }^{1} \mathrm{E}_{\mathrm{u}}$ respectively, which indicates square planar stereochemistry (Islam et al., 2002).

The Pt(II) complex gave three bands at 36,000 , 39,650 and $41,000 \mathrm{~cm}^{-1}$ corresponding to the transitions ${ }^{1} \mathrm{~A}_{1 \mathrm{~g}} \rightarrow{ }^{1} \mathrm{~B}_{1 \mathrm{u}},{ }^{1} \mathrm{~A}_{1 \mathrm{~g}} \rightarrow{ }^{1} \mathrm{E}_{\mathrm{u}}$ and ${ }^{1} \mathrm{~A}_{1 \mathrm{~g}} \rightarrow{ }^{1} \mathrm{~A}_{2 \mathrm{u}}$, respectively. All of these bands are characteristic of a square-planar Pt(II) complex (Islam et al., 2002). Electronic spectral data are presented in Tables 3 and 4.

Antimicrobial activity: Antibacterial activity of target compounds was determined against Gram-positive bacteria (Listeria monocytogenes, Staphylococcus aureus,
Enterococcus faecalis) and Gram-negative bacteria (Psudomonas aeruginosa, Salmonella bovis morbificans, Salmonella typhi, Escherichia coli). Results from the agar disc diffusion tests for antibacterial activity are presented in Table 4 and illustrated in Figures 4 and 5. The diameters of zone of inhibition (in $\mathrm{mm}$ ) of the standard drug kanamycin against bacteria Pseudomonas aeruginosa (Gram negative), Salmonella bovis morbificans (Gram negative), Salmonella typhi (Gram negative), Escherichia coli (Gram negative), Listeria monocytogenes(Gram positive), Staphylococcus aureus (Gram positive), Enterococcus faecalis (Gram positive) were found to be $22,22,20,20,25,23$, and $21 \mathrm{~mm}$, respectively \& the graphical comparision of zone of inhibition are shown in Fig. 6. Under identical conditions, Table 4 shows that complex 1 has 12, 0,21,23,26,18 and $10 \mathrm{~mm}$, complex 2 has $38,25,21,30,21,34$ and $12 \mathrm{~mm}$, complex 3 has 32 , 33, 33, 40, 41, 12 and $17 \mathrm{~mm}$, for Pseudomonas aeruginosa, Salmonella bovis morbificans, Salmonella typhi, Escherichia coli, Listeria monocytogenes, Staphylococcus aureus, Enterococcus faecalis, respectively. The complexes containing 2-aminopyridine and 4-picoline as secondary ligands are much more microbial active than the other complexes. Moreover, the complexes $\left[\mathrm{Pd}(\mathrm{Ph})(2\right.$-apy) $]$ and $\left[\mathrm{Pt}(\mathrm{Ph})(4-\text { pico })_{2}\right]$ show the highest antibacterial activity against all bacteria tested. From the data it may conclude that our synthesized complexes have show mild to moderate antibacterial activity.

Table 1. Elemental analyses and physical properties of the synthesized complexes.

\begin{tabular}{|c|c|c|c|c|c|c|c|c|c|}
\hline Compd \# & $\begin{array}{l}\text { Complexes } \\
\text { (Colour) }\end{array}$ & $\begin{array}{c}\text { Yields } \\
\%\end{array}$ & $\begin{array}{l}\text { Metal } \\
\%\end{array}$ & $\begin{array}{c}\text { Carbon } \\
\%\end{array}$ & $\begin{array}{c}\text { Hydrogen } \\
\%\end{array}$ & $\begin{array}{l}\text { Nitrogen } \\
\%\end{array}$ & $\begin{array}{l}\text { Melting } \\
\text { point } \\
\left( \pm 5^{\circ} \mathrm{C}\right)\end{array}$ & $\begin{array}{c}\mathrm{A}_{\mathrm{M}} \\
\left(\mathrm{ohm}^{-1} \mathrm{~cm}^{2}\right. \\
\left.\mathrm{mol}^{-1}\right)\end{array}$ & $\begin{array}{c}\mu_{\mathrm{eff}} \\
(\mathrm{BM} .)\end{array}$ \\
\hline 1 & $\begin{array}{l}\mathrm{Pd}(\mathrm{Ph})(\mathrm{Py})_{2} \\
(\text { YellowGreen) }\end{array}$ & 72 & $\begin{array}{c}24.85 \\
(24.82)\end{array}$ & $\begin{array}{c}50.35 \\
(50.42)\end{array}$ & $\begin{array}{c}3.35 \\
(3.29)\end{array}$ & $\begin{array}{c}6.50 \\
(6.54)\end{array}$ & 260 & 10.80 & Dia \\
\hline 2 & $\begin{array}{l}\mathrm{Pd}(\mathrm{ph})(2 \text {-apy) } \\
\text { (YellowGreen) }\end{array}$ & 67 & $\begin{array}{c}29.10 \\
(29.18)\end{array}$ & $\begin{array}{c}42.75 \\
(42.81)\end{array}$ & $\begin{array}{c}2.70 \\
(2.76)\end{array}$ & $\begin{array}{c}7.70 \\
(7.68)\end{array}$ & 258 & 11.30 & Dia \\
\hline 3 & $\mathrm{Pt}(\mathrm{ph})(4-\mathrm{pico})_{2}($ Yellow $)$ & 72 & $\begin{array}{c}35.70 \\
(35.77)\end{array}$ & $\begin{array}{c}44.13 \\
(44.03)\end{array}$ & $\begin{array}{c}3.40 \\
(3.33)\end{array}$ & $\begin{array}{c}5.11 \\
(5.14)\end{array}$ & 250 & 10.65 & Dia \\
\hline
\end{tabular}

Table 2. Infrared spectral data of the complexes (band maxima in $\mathrm{cm}^{-1}$ ).

\begin{tabular}{clcccccc}
\hline Compd. \# & Complexes & $v(\mathrm{OH})$ & $v(\mathrm{~N}-\mathrm{H})$ & $v(\mathrm{C}=\mathrm{O})$ & $v(\mathrm{C}-\mathrm{O})$ & $v(\mathrm{M}-\mathrm{O})$ & $v(\mathrm{M}-\mathrm{N})$ \\
\hline 1 & $\mathrm{Pd}(\mathrm{Ph})(\mathrm{Py})_{2}$ & - & - & 1659.6 & 1399.3 & 512.1 & 421.4 \\
2 & $\mathrm{Pd}(\mathrm{Ph})(2-\mathrm{apy})$ & - & 3320.2 & 1633.6 & 1385.8 & 537.1 & 463.8 \\
3 & $\mathrm{Pt}(\mathrm{Ph})(4-\mathrm{pico})_{2}$ & - & - & 1610.0 & 1390.0 & 510.0 & 470.0 \\
\hline
\end{tabular}


Table 3. Electronic spectral data $\left(\mathrm{cm}^{-1}\right)$ of square planar Palladium(II) complexes.

\begin{tabular}{lccccc}
\hline Complexes & \multicolumn{5}{c}{ Spectral band $\left(\mathrm{cm}^{-1}\right)$ with assignment } \\
\cline { 2 - 5 } & ${ }^{1} \mathrm{~A}_{1 \mathrm{~g}} \rightarrow{ }^{1} \mathrm{~A}_{2 \mathrm{~g}}$ & ${ }^{1} \mathrm{~A}_{1 \mathrm{~g}} \rightarrow{ }^{1} \mathrm{~B}_{1 \mathrm{~g}}$ & ${ }^{1} \mathrm{~A}_{1 \mathrm{~g}} \rightarrow{ }^{1} \mathrm{E}_{\mathrm{g}}$, & ${ }^{1} \mathrm{~A}_{1 \mathrm{~g}} \rightarrow{ }^{1} \mathrm{~A}_{2 \mathrm{u}}$ & ${ }^{1} \mathrm{~A}_{1 \mathrm{~g}} \rightarrow{ }^{1} \mathrm{E}_{\mathrm{u}}$ \\
\hline $\mathrm{Pd}(\mathrm{Ph})(\mathrm{Py})_{2}$ & 23050 & 28300 & 31000 & 34800 & 40000 \\
$\mathrm{Pd}(\mathrm{Ph})(2$-apy $)$ & 22800 & 28300 & 31300 & 35000 & 40200 \\
\hline
\end{tabular}

Table 4. Electronic spectral data $\left(\mathrm{cm}^{-1}\right)$ of square planar Platinum(II) complex.

\begin{tabular}{cccc}
\hline Complex & \multicolumn{3}{c}{ Spectral band $\left(\mathrm{cm}^{-1}\right)$ with assignment } \\
\cline { 2 - 4 } & ${ }^{1} \mathrm{~A}_{1 \mathrm{~g}} \rightarrow{ }^{1} \mathrm{~B}_{1 \mathrm{u}}$ & ${ }^{1} \mathrm{~A}_{1 \mathrm{~g}} \rightarrow{ }^{1} \mathrm{E}_{\mathrm{u}}$ & ${ }^{1} \mathrm{~A}_{1 \mathrm{~g}} \rightarrow{ }^{1} \mathrm{~A}_{2 \mathrm{u}}$ \\
\cline { 2 - 4 } $\mathrm{Pt}(\mathrm{Ph})(4-\text { pico })_{2}$ & 36,000 & 39,650 & 41,000 \\
\hline
\end{tabular}

where, $\mathrm{Dia}=$ Diamagnetic, $\mathrm{Ph}=$ Diprotonated phthalic acid, $\mathrm{Py}=$ pyridine, 2 apy $=2$-aminopyridine, 4-pico=4-picoline

Table 5. Results of the antibacterial activity of the complexes.

\begin{tabular}{lcccc}
\hline \multirow{2}{*}{ Test organism } & \multicolumn{4}{c}{ Diameter of zone inhibition $(\mathrm{mm})$} \\
\cline { 2 - 5 } & $\mathrm{Pd}(\mathrm{Ph})(\mathrm{Py})_{2}$ & $\mathrm{Pd}(\mathrm{Ph})(2$-apy $)$ & $\mathrm{Pt}(\mathrm{Ph})(4-\mathrm{pico})_{2}$ & Kanamycin $30 \mu \mathrm{g} / \mathrm{disc}$ \\
\hline Pseudomonas aeruginosa $(-\mathrm{ve})$ & 12 & 38 & 32 & 22 \\
Salmonella bovis morbificans $(-\mathrm{ve})$ & 0 & 25 & 33 & 22 \\
Salmonella typhi $(-\mathrm{ve})$ & 21 & 21 & 33 & 20 \\
Escherichia coli $(-\mathrm{ve})$ & 23 & 30 & 40 & 20 \\
Listeria monocytogenes $(+\mathrm{ve})$ & 26 & 21 & 41 & 25 \\
Staphylococcus aureus $(+\mathrm{ve})$ & 18 & 34 & 12 & 23 \\
Enterococcus faecalis $(+\mathrm{ve})$ & 10 & 12 & 27 & 21 \\
\hline
\end{tabular}

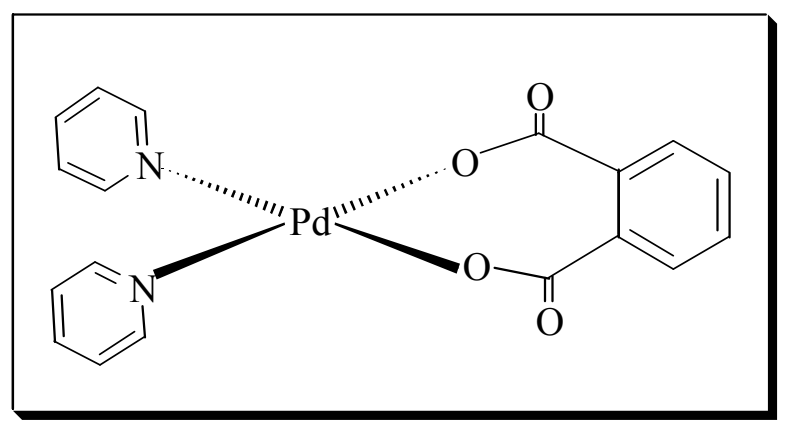

Figure 1(a). Possible structure of the complex-1 $\left[\mathrm{Pd}(\mathrm{II})(\mathrm{Ph})(\mathrm{Py})_{2}\right]$.

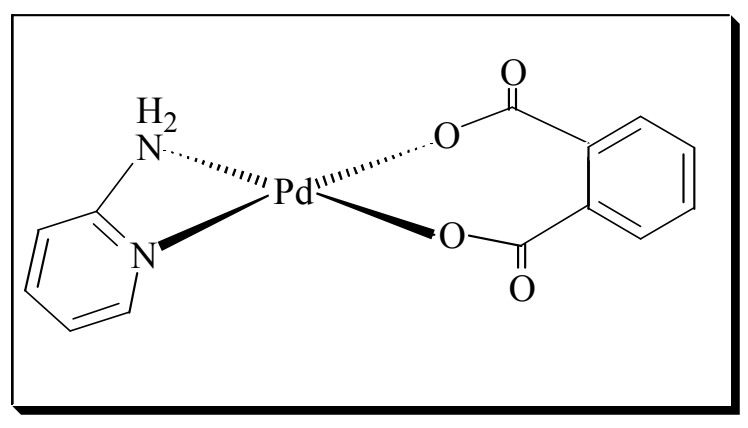

Figure 2(a). Possible structure of the complex-2 $[\mathrm{Pd}(\mathrm{II})(\mathrm{Ph})(2-$ apy)].

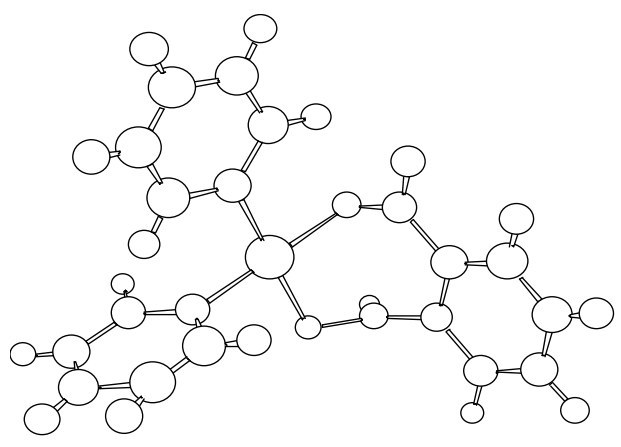

Figure 1(b). Possible ball and stick model of the complex-1 $\left[\mathrm{Pd}(\mathrm{II})(\mathrm{Ph})(\mathrm{Py})_{2}\right]$.

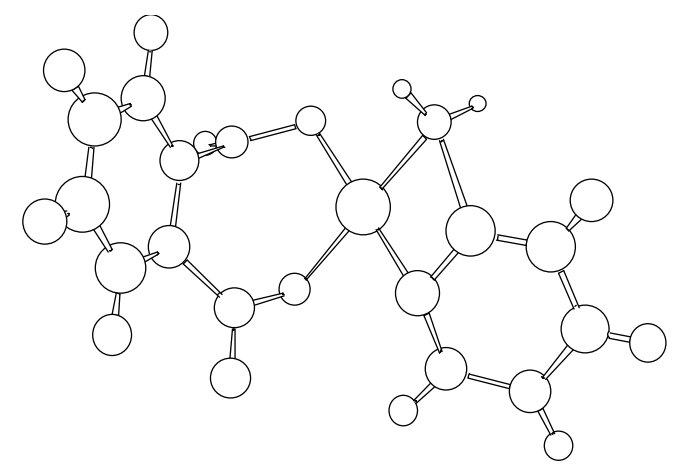

Figure 2(b). Possible ball and stick model of the complex-2 $[\mathrm{Pd}(\mathrm{II})(\mathrm{Ph})(2$-apy)]. 

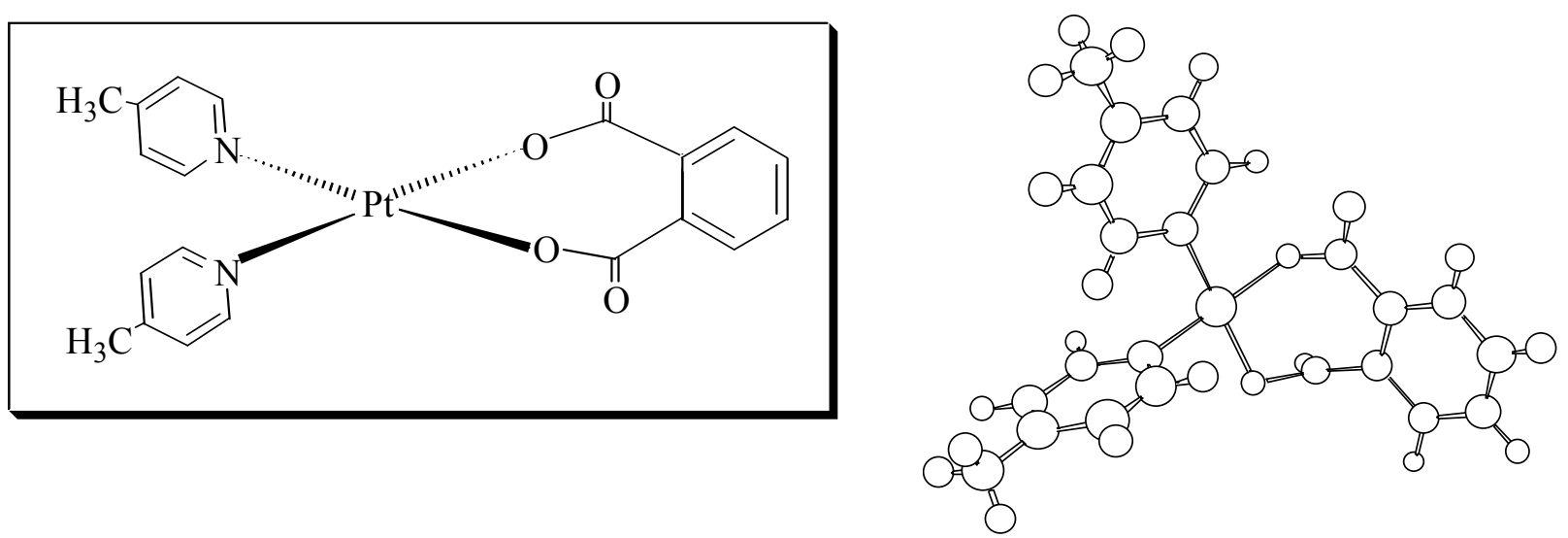

Figure 3(a). Possible structure of the complex-3 [Pt(II)(Ph)(4-pico $\left.)_{2}\right] . \quad$ Figure 3(b). Possible ball and stick model of the complex-3 [Pt(II)(Ph)(4-pico $\left.)_{2}\right]$.

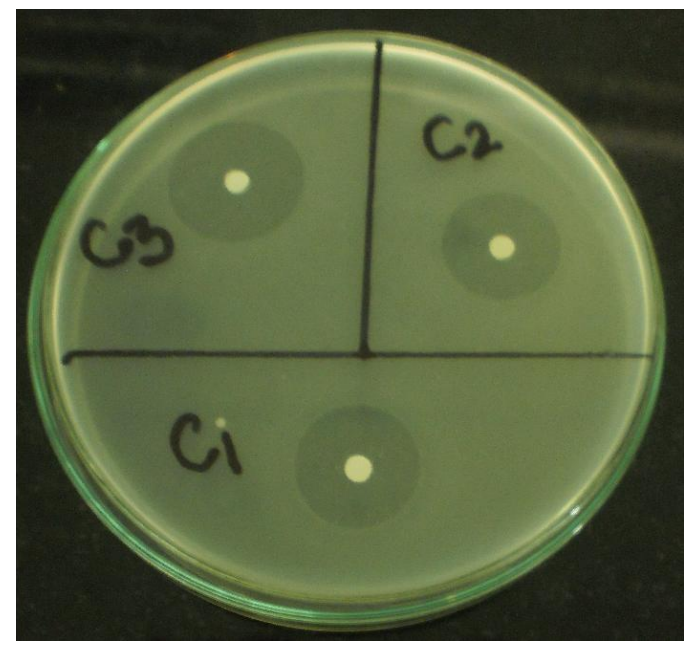

Figure 4. Photographic representation of zone of inhibition of complexes 1,2 and 3, respectively against Salmonella typhi

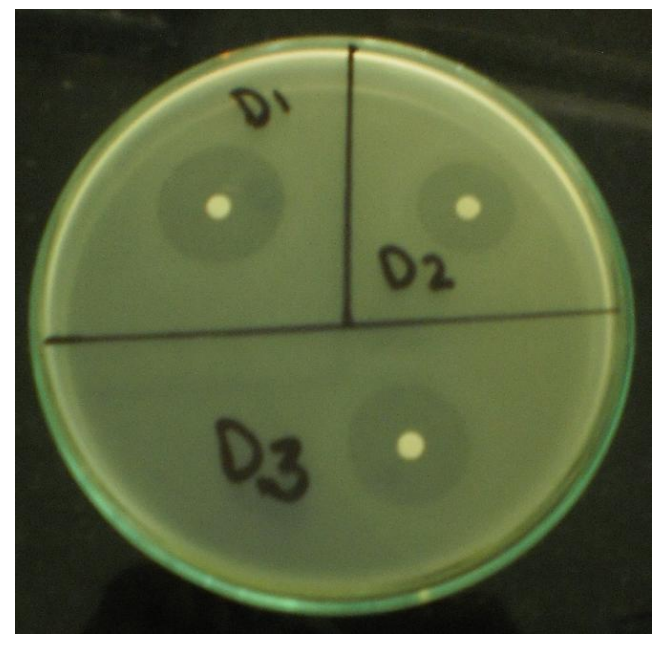

Figure 5. Photographic representation of zone of inhibition of complexes 1, 2 and 3, respectively against Escherichia coli

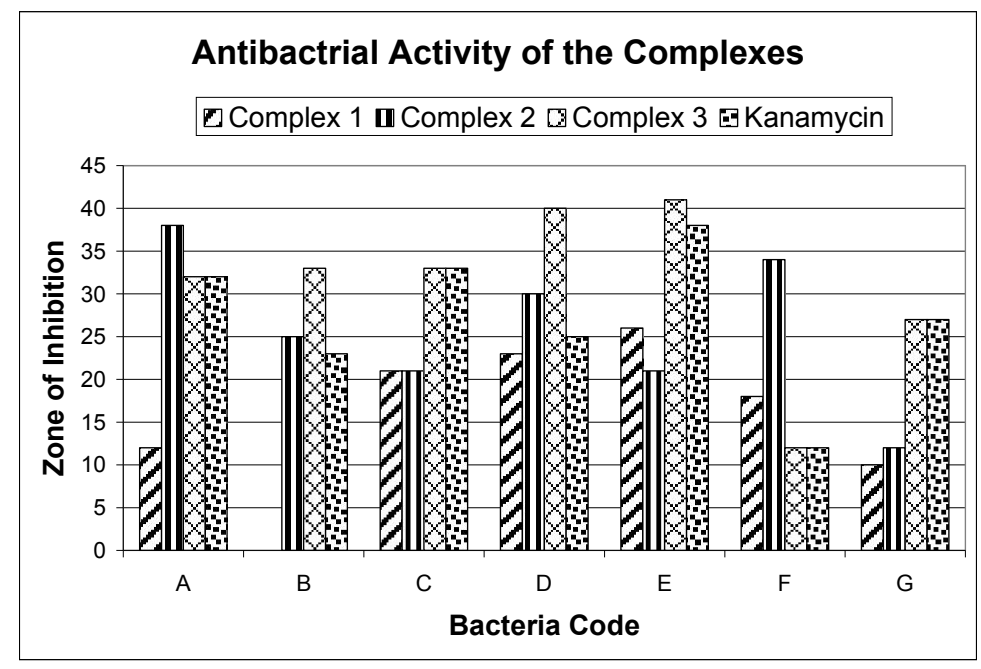

Figure 6. Comparision of zone of inhibition of the complexes with standard 


\section{Conclusion}

From the above discussion, it is evident that the prepared $\mathrm{Pd}(\mathrm{II})$ and $\mathrm{Pt}(\mathrm{II})$ complexes are square planar in structure and the probable structures of the complexes have been shown in figures 1-3. Antibacterial screening of our synthesized complexes have shown mild to moderate activity.

\section{References}

Anshu, S. 2011. Synthesis and structural investigations of coordination compounds of palladium with 2-methyl imidazole. Int. J. App. Pharm. 3, 1415.

Baur, A.W., Kirby W.M.M. and Turck, M. 1966. Antibiotic susceptibility testing by standardized single disc method. Am. J. Clin. Pathol. 44, 493-496.

Biyala, M.K., Sharma, K., Swami, M., Fahmi, N. and Singh, V. R. 2008. Spectral and biocidal studies of palladium(II) and platinum(II) complexes with monobasic bidentate Schiff bases. Transition Met. Chem. 33, 377-381.

Edit, F., Agota, D., Adrian, P., Attila-Zsolt, K., Ionut, B.C., Leontin, D. and Ioan, S. D. 2010. Synthesis, structure and $\mathrm{dft}$ calculations on complexes of palladium(II) with theophylline. Rev. Roum. Chim. 55, 697-704.

Eryazici, I., Moore, W.C.N., Newkome, G.R. 2008. Squareplanar $\mathrm{Pd}(\mathrm{II}), \mathrm{Pt}(\mathrm{II})$, and $\mathrm{Au}(\mathrm{III})$ terpyridine complexes: their syntheses, physical properties, supramolecular constructs, and biomedical activities. Chem Rev. 108, 18341895.

Hossain, M.B., Islam M.S., Islam, M.R., Salam, M.A. and Yousuf, M.A. 2012. Synthesis and characterization of mixed ligand complexes of $\mathrm{Co}(\mathrm{II})$ and $\mathrm{Fe}(\mathrm{III})$ ions with maleic acid and heterocyclic amines. J. Bangladesh Chem. Soc. 25, 139-145.

Hossain, M.B., Hossain, M.M. and Islam, M.S. 2004. Synthesis and characterization of mixed Ligand complexes of $\mathrm{Pt}(\mathrm{IV})$ and $\mathrm{Ni}(\mathrm{II})$ ions with phthalic acid and heterocyclic amines. J. Bangladesh. Chem. Soc. 17, 177-182.

Hossain, M.B., Yousuf, M.A., Islam, M.R, Salam, M.A., Rahman, M.A. and Akbor, M.A. 2012. Synthesis and characterization of mixed ligand complexes of $\mathrm{Co}(\mathrm{II})$ and $\mathrm{Fe}(\mathrm{III})$ ions with malic acid and heterocyclic amines. Bangladesh Pharm. J. 15, 177-181.

Islam, M.S., Farooque, M.A. and Bodruddoza, M.A.K. 2002. Synthesis and characterization of some thiocyanato complexes of $\mathrm{Ni}(\mathrm{II}), \mathrm{Cu}(\mathrm{II}), \mathrm{Pd}(\mathrm{II}), \mathrm{Pt}(\mathrm{II}), \mathrm{Au}(\mathrm{III}), \mathrm{Ti}(\mathrm{III})$ and V(IV) containing a tridentate Schiff base ligand. Synth. React. Inorg. Met-Org. Chem. 32, 1811-1823.
Islam, M.S., Hossain, M.B. and Reza, M.Y. 2003. Antimicrobial studies of mixed ligand transition metal complexes of maleic acid and heterocyclic bases. J. Med. Sci. 3, 289-293.

Islam, M.S., Hossain, M.B. and Reza, M.Y. 2004. Synthesis and characterization of mixed ligand complexes of Co(II) And $\mathrm{Fe}(\mathrm{III})$ ions with malonic acid and heterocyclic amines. Indian. J . Chem. 43A, 1897-1900.

Islam, M.S., Roy, R.K. and Miah, M.A.J. 1991. Mixed ligand complexes of Pd(II), Rh(II) and Pt(II) succinato with 1,10Phenanthroline and 2,2-Bipyridine. Synth. React. Inorg. Met-Org. Chem. 21, 873-875.

Kuduk-Jaworska, J., Puszko, A., Kubiak, M. and Peiczyjska, M. 2004. Synthesis, structural, physico-chemical and biological properties of new palladium(II) complexes with 2,6dimethyl-4-nitropyridine. J. Inorg. Biochem. 98, 1447-1456.

Pablo, E and Jesu, S.A.M. 1996. Palladium complexes with the tridentate dianionic ligand pyridine-2,6-dicarboxylate, dipic. crystal structure of $\left[\mathrm{Pd}(\mathrm{dipic})\left(\mathrm{PBu}_{2}\right)\right]_{2}$. Inorg. Chem. 35, 2287-2291.

Pandey, R.N., Gunjan, K., Nag, A.K. and Kirti, V.G. 2010. Mixed-ligand organometallic complexes of ruthenium (II) palladium (II) and platinum(II) with triphenyl phosphine and 2-mercaptobenzothiazole. Rasayan J. chem. 3, 415-419.

Reza, M.Y., Hossain, M.B. and Islam, M.S. 2003. Antimicrobial studies of mixed ligand transition metal complexes of phthalic acid and heterocyclic bases. Pak. J. Biol. Sci. 6, 1494-1496.

Reza, M.Y., Hossain, M.B. Islam, M.S. and Alam, S. 2003. Antimicrobial studies of mixed ligand transition metal complexes of malonic acid and heterocyclic bases. Pak. J. Biol. Sci. 6, 1314-1316.

Rios, J.J., Reico, M.C. and Villar, A. 1988. Antimicrobial screening of natural products. J. Enthopharmacol. 23, 127 159.

Sarmistha, H., Michael, G.B.D and Samaresh, B. 2008. Palladium and platinum complexes of 2-(2'carboxyphenylazo)-4-methylphenol: synthesis, structure and spectral properties. J. Chem. Sci. 120, 441-446.

Shayma, A.S. 2010. Preparation and spectral properties of mixed-ligand complexes of V(IV), Ni(II), Zn(II), Pd(II), $\mathrm{Cd}(\mathrm{II})$ and $\mathrm{Pb}(\mathrm{II})$ with dimethylglyoxime and $\mathrm{N}$ Acetylglycine. Eu. J. Chem. 7, 580-586.

Vogel, A.I. 1961. A Text-Book of Quantitative Inorganic Analysis, 3rd edn. ELBS and Longmans, Green \& Co. Ltd. London. 